\title{
Interpreting Undergraduate Research Posters in the Literature Classroom
}

\author{
ABSTRACT \\ This essay explores the use of undergraduate research posters in English literature classrooms; \\ at the same time, it argues for a scholarship of teaching and learning responsive to how \\ meaning is constructed in the arts and humanities. Our scholarly practice requires interaction \\ with texts and with each other, yet the undergraduate research paper typically does not \\ involve much interaction between peers. The posters disseminate preliminary interpretations \\ of research projects to peers; they are a way to make visible some of the cognitive, affective, \\ and aesthetic aspects of literary research. This essay analyzes student reflections on both the \\ process of creating and the process of presenting research posters before providing "close \\ readings" of several posters. Reading the posters reveals key elements of students' \\ interactions with literary texts: close reading, integration, negotiation, theoretical \\ generalization, and aesthetic judgment. As the students explored a less familiar genre, \\ disciplinary processes of knowledge creation were defamiliarized and made visible.
}

\section{KEYWORDS}

undergraduate research, English, scholarship of teaching and learning, research posters, literature

As an English teacher and scholar, I have been searching for ways to "make visible" the processes involved in literary research. This lovely phrase is woven through much SoTL scholarship, including Connie Schroeder and Anthony Ciccone's (2005) Making Learning Visible, the Visible Knowledge Project led by Randy Bass, Jeff Bernstein's (2008) helpful question “Making Learning Visible for Whom?” and Nancy Chick's (2013) "Beyond the Essay: Making Student Thinking Visible in the Humanities." As I think about the many processes involved in literary research, processes I have done for so long that I cannot clearly remember how I learned to do them, I recognize a key conceptual shift from seeing research as an exercise in finding and using information to seeing research as the creation and communication of knowledge. Research posters can help make this shift visible for instructors, for students, and perhaps for larger communities.

I teach English at a public undergraduate university in Western Canada. Our university, like many in North America, is actively promoting undergraduate research, but often students don't recognize literary research as research, as an activity that can make "an original intellectual or creative contribution to a discipline," to quote the Council for Undergraduate Research's (2011) definition. Rather, many see literary research as an exercise in finding and repeating what others have said about a particular text, a misconception shared by some faculty from other disciplines who may be willing to concede that we "research" our texts, but may be uncomfortable describing our articles as "research," preferring the more general, and by implication less rigorous, term "scholarship." Jennelle Kyd (2010) argues that the scholar seeks knowledge while the researcher generates it, and while she is willing to concede that people 
in the humanities may indeed be researchers, she describes this work in terms of generating and testing hypotheses, terms which many humanists distrust as inadequate to represent human experience in its myriad forms. This tension between research and scholarship, between research as a noun and research as a verb, spills into discussions of arts and humanities SoTL (Manarin, 2015) and articles like this one. Even as I hope to influence my disciplinary colleagues' practices by providing the arguments and evidence that they will find convincing, I need to explain those practices and justify my methodological choices to those who do not understand how we create knowledge within the discipline. ${ }^{1}$

Laura Behling (2009) describes literary research or scholarship (we usually use the two words interchangeably) as

hermeneutical, exploratory, analytical, and interpretive. In literary studies, we begin with an idea or argument and the process of gathering evidence and investigating often changes that argument or thesis. We don't conduct experiments; we have a different understanding of what it means to collect data (we don't even call it 'data'); we admit that our critical philosophies affect our readings; and writing about our inquiries shapes and even changes our interpretations. What we need to conduct research is far different than in other disciplines. We consider a thesis different than a hypothesis, and we don't work according to the scientific method. Our written analyses look far different than a scientific paper. (p. 4)

Literary research is typically an individual rather than collaborative endeavor. We don't usually follow a predetermined method that can be divided into specific steps or easily explained to students. The products of our scholarship, our peer-reviewed articles, do not often lay out the inquiry in easy to model chunks separated by subheadings. Our dominant methodology, as Randy Bass and Sherry Linkon (2008) have argued, is close reading inflected by different theoretical frames, but we rarely make explicit the assumptions underlying our selection of evidence, our theoretical frame, our use of secondary sources, or our tacit agreement about the rules of interpretation. Janet Gail Donald (2009) claims that, while the engineer may judge based on the validation question "Does it work?", the literary scholar relies on the question "Do you agree?" But such a question does not countenance relativism. Stanley Fish (1980) argues that an interpretation can be considered acceptable, not if members of an interpretive community agree with it, but if they are willing to consider it seriously enough to argue against it. The rules of such engagements are perhaps more powerful, certainly more mysterious, because they are largely unspoken. Most of us did not learn how to do research in any systematic way. Our professors modeled close reading and interpretation, and we just sort of muddled along reading articles and writing research papers.

These research papers can too easily become the fetishized end product of a process shrouded in secrecy, any insights shared only with a reader who is assumed to know more about the subject than the author. The undergraduate research paper often seems to be an exercise in formatting rather than knowledge creation. Alison Head and Michael B. Eisenberg (2010), examining research assignment instructions from various courses at colleges across America, found that, while most provided detail on number of sources, documentation style and formatting, very few provided any guidance on how to read or evaluate sources. Sherry Linkon (2011), looking more specifically at the English major, argues that "Perhaps the most common error we make is giving assignments that provide extensive detail about technical requirements but offer minimal description of the intellectual task of doing literary research" (p. 84). Linkon offers examples of the types of content and strategic knowledge students need to 
succeed in the research paper. She argues for a type of cognitive apprenticeship to foreground the process of literary inquiry with multiple short assignments and frequent feedback.

Frustrated with traditional research papers and believing in the value of undergraduate research for all students, I wondered what would happen if we provided English majors with the opportunity to experience more closely what we as English scholars do. What if we focused on the processes of literary research? What if we paid more attention to inquiry as the creation of knowledge through scholarly conversation, with each other and with our primary and secondary sources, rather than focusing almost exclusively on how to record the "results" of inquiry in the research paper? With these questions in mind, I redesigned four senior-level English classes. Dissemination is an integral part of the research process, but given the class sizes ranging from 23 to 28 students, I could not provide the opportunity for students to read their papers in conference format, a common mode of dissemination in English studies. Instead, I included poster sessions, a type of dissemination far more common in science and social science disciplines but gaining attention from some humanities scholars. David Reichard, for example, describes history students learning about selection of evidence through research posters (Reichard \& Takayama, 2013, p. 174) while Chick (2013a) argues that a poster can be an authentic alternative to the research essay for humanities classes. The posters in my classes were intended to disseminate preliminary interpretations to peers; they were not the final product, as students still wrote papers on these topics, but they were a way to make visible some of the cognitive, affective, and aesthetic aspects of literary research. I include the term "aesthetic" because the posters themselves did not follow the standard research poster templates taken from science; instead, students were free to experiment with format and materials, as Chick (2011) has recommended. Almost all students attempted to represent thematic elements of their projects in the aesthetic choices for their posters; some went further to create aesthetic artifacts in dialogue with the primary texts. In what follows, I offer some general comments about the poster process before "reading" a few specific posters and the reflections that accompany them, as I would other texts. I read closely, looking for patterns and creating my interpretations of student learning. Chick (2013b) compares this sort of meaning-making to Glaser and Strauss's process of grounded theory: "an inductive, iterative, systematic process of analyzing and reanalyzing data (or text) to build towards a theory (or interpretation, or our process of meaning making)" (p. 23). I highlight aspects of student learning often obscured in the research paper and make claims about how learning may work in this context, and perhaps in other contexts. As my students explored a less familiar genre, disciplinary processes of knowledge creation were defamiliarized and made visible.

\section{POSTERS IN THE LITERATURE CLASSROOM}

Before I present my reading of these posters in terms of student learning, however, it is important to share some of the details around these courses. After all, as Liz Grauerholz and Eric Main (2013) note, teaching methods are "social acts informed by cultural traditions that become most meaningful when described in terms of specific histories and larger social contexts" (p. 158). In 20112012, I redesigned a fourth-year seminar on the Gothic and a third-year course on Romanticism to focus more explicitly on the process of literary research; in the fall term of 2013, I offered the Gothic seminar again and a different third-year Romanticism course. In the Gothic seminars, students were expected to produce original undergraduate research on either an $18^{\text {th }}$ century text or modern phenomena connected to the $18^{\text {th }}$ century Gothic canon. They chose to work on everything from little-known Gothic novels like The Spectre (1788), The Orphan of the Rhine (1798), or Clermont (1798) to the films of Tim Burton, Scooby Doo, zombie girl tattoos, and Japanese Manga. Over the term, students completed a series of assignments designed to lead them through the research process, from developing 
an area of inquiry through choosing a theoretical frame, making a claim, and eventually incorporating feedback from the poster session. A significant amount of class time was devoted to the undergraduate research process. The Romantic literature courses were more traditional in that students had the option of original research for the final paper, but most chose to do a form of synthesis research where they examined a Romantic text that had been written about before and tried to add something to the discussion. A focus in these third-year courses was how to read secondary sources as students completed a series of worksheets leading them through scholarly articles. In both the fourth-year seminars and third-year courses, students were required to create posters and write two reflective pieces about the poster process, one completed at the time of the poster presentation and one when the final paper was handed in. Thus, the posters embody a set of cognitive and aesthetic choices made at a particular moment in the research process; the reflective writing narrates these choices.

For each of these courses, students were divided into two groups roughly two weeks before the final paper was due. During one class, students in the first stood by their posters, while the other group circulated and asked questions; the following class, the roles were reversed. The posters needed to include a thesis, some indication of the theoretical frame, and examples of the evidence that would be used in the final paper. I did not assess the posters using a rubric based on key elements listed in this essay, elements like close reading, theoretical generalization, and aesthetic judgment. As long as the students included the required elements on the poster and were able to discuss their projects with their peers and me, they received at least a $\mathrm{B}$, and they knew that going into the exercise. In the four classes I am considering here, only a handful of students did not respond effectively to the task. Occasionally the posters were missing a thesis or theoretical frame. For those students, the poster session was particularly important as it provided me with an opportunity to intervene before the research paper. In two or three cases, students had all the elements but put together posters without regard for visual impact. However, the reflective pieces that the students handed in with the poster and with the research paper required that students describe the decisions they made in disseminating their research. These one-page assignments reinforced the idea that dissemination, whether in poster or essay form, is a rhetorical act. The poster sessions in particular allowed me to frame research as knowledge creation that should be presented publicly for peer review and critique. ${ }^{2}$

\section{REFLECTING ON POSTERS}

When I had conceptualized the courses, I had thought of the poster as an opportunity for students to create a visual outline of their papers, begin thinking about their papers earlier, and get some feedback for those papers. And indeed, students often reported the first two items in their reflections and the interviews. Students talked about beginning to work on their projects far earlier than they typically do, so they felt less pressure later on. Many students identified the visual nature of the poster as helpful, particularly in a discipline as text-heavy as English. The poster revealed elements, like the organization of ideas rather than just the organization of paragraphs, that are too often taken for granted in the research paper. Because it was a visual rather than textual genre, the poster served to defamiliarize literary research; the students focused on communicating ideas about their primary texts instead of hiding behind words, their own and the critics'. Students said things like "I think it was just to get the ideas out...and make them visible. For me at least, I am a very visual person so when I can see it all laid out, and I can see what other people are doing and their ideas, it helps me to organize my ideas more." Although I am dubious about self-diagnosed learning styles and their efficacy, this student identifies a key component of literary research: the community where we learn from each other's interpretations. Our scholarly practice requires interaction with texts and with each other, yet the research paper typically 
does not involve much interaction between peers beyond perhaps a peer review session where students read each other's papers and offer comments. Another student, when asked whether the creation or the presentation of the poster was more important, refused to choose, saying that the whole process helped:

So it helped me format my paper in my head and then kind of think about the littler details, so again, the color scheme--what they might be trying to get at--that maybe I would have missed before when just talking in broader terms, it helped me bring things more specifically in there, and then, again, the presentation was mostly to help me become confident that I was on the right track and to confirm to myself as I was telling people that this is exactly how I want to write my paper because I am saying things in this order.

Again this student focuses on the poster as an organizational tool that helped her develop her paper; she also has to make specific aesthetic choices to represent broader elements of text and argument. She is engaged in a process of selection and abstraction as she moves between "the littler details" and "what they might be trying to get at." She has to consider questions of representation as she works with three different genres: the primary text, the poster, and the research paper. She has to consider her audience. This poster audience becomes important for the research paper. Not only can she rehearse her argument, she emphasizes the confidence she gained as an author because of her interactions with peers.

Many students did not get as much feedback as they wanted from their peers. Most peer feedback involved suggesting resources, discussing theoretical frames, or asking for more detail; students were unlikely to challenge or criticize the ideas presented even though many students expressed regret that their peers had not engaged more critically with their ideas. They tended to shy away from the validation question: "Do you agree?" as an invitation to argue. This reluctance is not at all surprising given investigation about types of feedback in peer evaluation of writing (for example, Brammer \& Rees, 2007; Mulder, Pearce, \& Baik, 2014) or, for that matter, given most conference interactions I've witnessed. As I think through this activity for future classes, I am developing a set of prompts students can use to elicit, and provide, more critical feedback for each other. I let students know that their peers are likely to begin by commenting on the aesthetic elements of the poster and tell them that their task is to try to engage their peers about the ideas presented. I encourage students commenting on the poster to use more open-ended questions: "What drew you to this topic?"; "Why did you pick those examples for your poster?"; "What are you responding to here?" and, although this is the hard one, "Why does this detail/example/argument matter?"

Even with limited feedback, however, the poster sessions emphasized the process of dissemination as an intellectual conversation. Students positioned themselves and each other as creators of knowledge, and they identified the poster presentation rather than its creation as key. The important element seemed to be having to explain their ideas, over and over again: "Through repeatedly discussing my text - repetitively presenting and subsequently revising my 'spiel'-I soon realized the trajectory I wished to take with my paper and the necessary claims and information which it required." Discussing the poster with peers allowed students to work through different issues they were having with the project (what I've always hoped for from peer review sessions for papers), but the effect seemed magnified by the number of peers involved and the amount of explanation required. Perhaps because a traditional peer review session is based on an artifact already shaped by many words, students too often default into copyediting, rather than intellectual inquiry. These sessions often focus on shaping the final product instead of the process of knowledge creation. Here students were focused the deeper structures of how literary scholars think about texts rather than the surface elements of how we represent knowledge. 
Many students talked about their increased confidence in their projects because of their peers. They were surprised that they knew so much about their topics; they were excited that other people found their topics interesting; they were impressed by each other's work. As one student noted,

As I stood by my poster and watched the class wandering around discussing each other's projects, I realized how helpful this class has been to bring our individual projects into an area that allowed [us] to gain a collective respect for each other. Our projects have forced us all into our own research and could have kept us all there, but we were pushed to ask questions and give feedback to each other. The idea of making a poster and being put into a place of being vulnerable to the scrutiny of our fellow classmates was completely terrifying for most, but as soon as we started our session, the atmosphere of the class shifted and the whole situation was rather fun.

As this student describes the poster session, she makes visible learning that has little to do with the content of the posters. She describes a transformation of the classroom into an intellectual community that involves vulnerability, respect, and, for this student anyway, fun. Another student described knowing her classmates socially, but here she had the chance to talk with them about ideas. Certainly, many students seemed to demonstrate an increased engagement with the research process because of the poster sessions. In terms of class dynamics, the papers themselves seemed almost anti-climactic; the important moment of dissemination had come earlier.

\section{READING THE POSTERS}

I had not expected these performative and affective elements of the poster presentation to be so important for student learning; I also had not expected the aesthetic elements of the posters themselves to be so important, and so revealing. And my surprise, on all three counts, reveals a certain willful blindness within my own discipline. English has had a long history of trying to justify itself, but its justifications are contradictory. We both make and distrust claims about the power of literary appreciation; we value the "close reading" proposed by the New Critics even as we criticize its apparently apolitical stance; we worry about readers and variation in interpretation; we struggle with how to handle affective dimensions of text. Despite attention to the performative aspects of rhetoric, various theoretical constructs of the reader, and close reading of literary artifacts, we are often uncomfortable with aesthetic judgments. Yet many of the posters were beautiful. Students knew that they had to attract other students over to their posters, and we had talked in class about the importance of larger font, visuals, and a limited amount of text. However, almost all students tried to match their aesthetic choices on the poster with the content of their argument. Some used aesthetic choices to reveal elements of the literary text; some tried to document their cognitive processes; some tried to embody their claim. The posters, then, allow students multiple ways to interact with literary text. Reading the posters, with attention to the aesthetic and cognitive choices, provides glimpses into student learning that may not be as evident within the formal constraints of a final research paper.

\section{Choices that reveal literary text}

Most posters included a brief summary of the literary text if it was something we had not read together in class. Some posters attempted reveal text through choices in color palette, texture, and layout. Consider, for example, a poster about the Japanese anime Sankerea, a love-triangle between a hero, a zombie-heroine, and her incestuous father. 


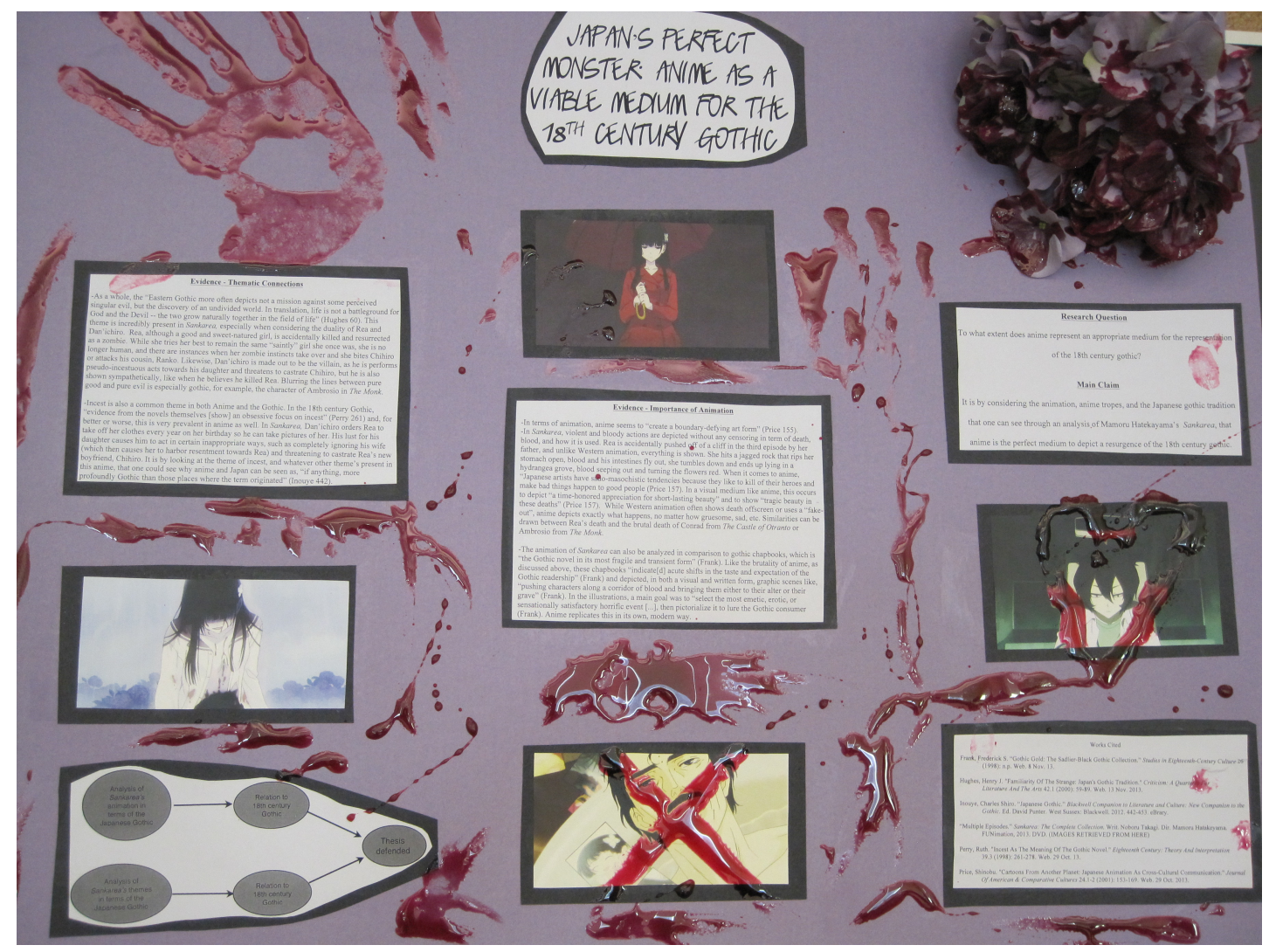

Each element of the poster contributes to the viewer's understanding of the text. The melancholic lavender complements the color scheme of the anime; the student added the bloody hand-print and symbols, as if the gory heroine was trying to communicate with the viewer; the blood-spattered hydrangea in the corner is a recurring motif in the text, symbolizing heartfelt emotions and alluding to the scene of the heroine's death. The poster also displays scenes from the graphic novel, important for the viewer to be able to understand the argument being made, but also important for the student creating the argument: "I found that staring at the images and color patterns that I put on my poster helped me think about what I wanted to say about anime's visuals and why they are so unique." But it is an interaction between the poster's creator and a viewer that creates a focused claim for the final paper:

At the presentations, someone suggested to me that it may be beneficial to include a discussion on the uncanny in my paper, but not only in regards to my paragraphs on incest. I had been told that I should use the uncanny to discuss the animation and how anime is different from Western cartoons. I never thought of connecting those dots before, but when I did, I was surprised at how easily the words seemed to flow. I was also told to clarify the path I was going to take to get to my point, which I believe I did in the final draft of my paper.

Precisely because the viewer was less familiar with the Japanese anime, he (or she) was able to make a connection that the student needs, but is too close to the topic to see. The images are uncanny, "unheimlich," familiar and strange, unsettling because attractive and repulsive at the same time. Interaction through a visual artifact, the poster, facilitated a conceptual link important for the paper. 


\section{Choices that highlight process}

Some posters highlighted the cognitive links made through the process of literary research, links often elided in the final research products. One poster, making a claim about Byron's poem "Sardanapalus," documented the student's research process.

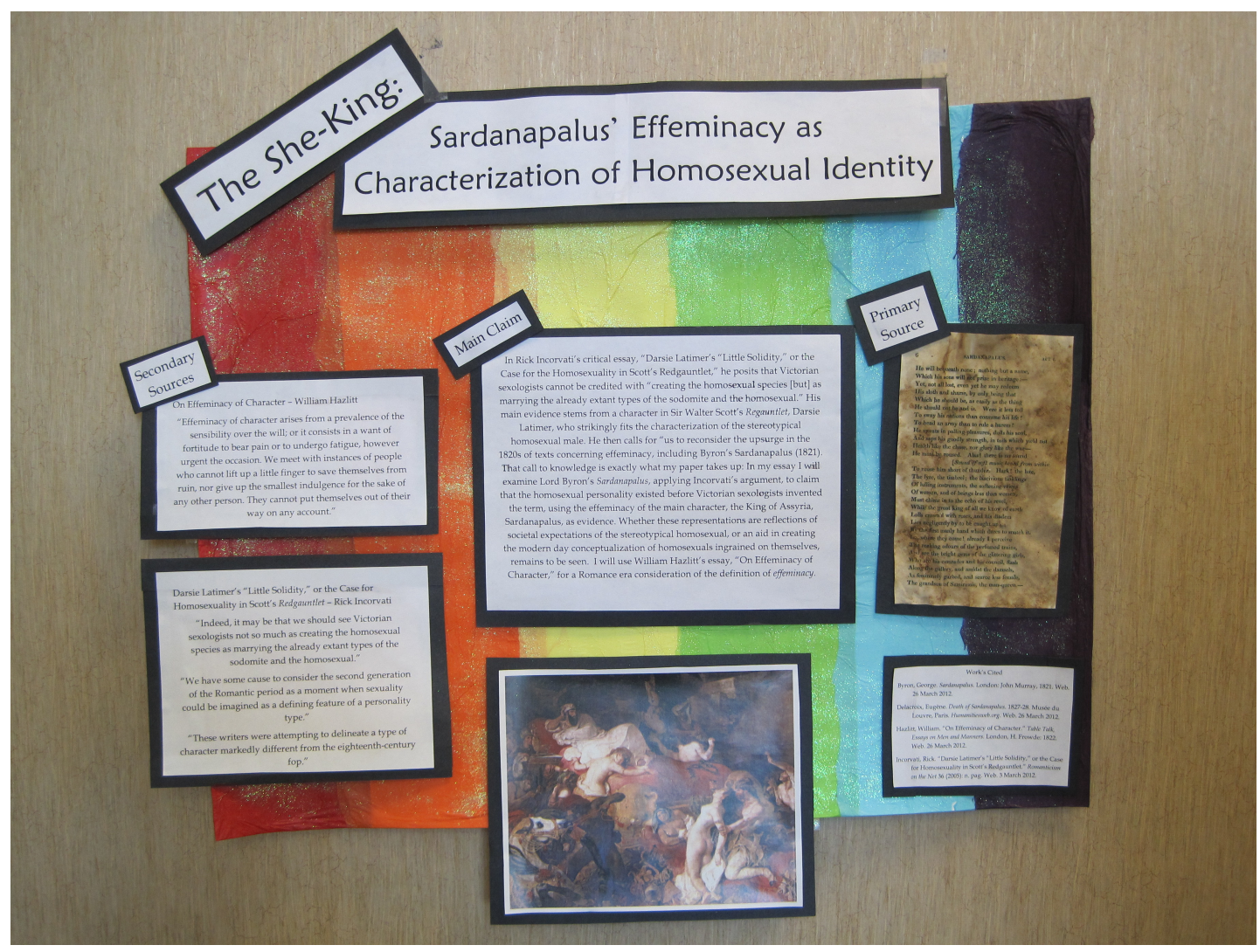

The decoupage rainbow background and glitter situate the student's argument within the framework of queer theory, and indeed this student began his research project wanting to do some sort of queer reading, but he did not have a primary text. Reading an essay about Sir Walter Scott, he came across a recommendation for further study and decided to follow it. This brief throw-away line is included on his poster as is a quotation from William Hazlitt's essay, "On Effeminacy" and a painting of Sardanapalus by Delacroix. The poster, then, reveals traces of the intellectual links the student made as he built his argument.

For some, building the poster was an aesthetic process that contributed to the argument. Take, for example, a poster about the sublime in Shelley's "Alastor" (see next page). The student argues that "Alastor" represents a negative sublime, that the main character's idealism ends in nihilism. In the finished poster, the negative silhouettes lead the viewer's eyes deeper into the poster's argument. However, the physical demands of creating this poster clarified the intellectual ones. Some of the concerns are practical:

Well, first of all, I can't draw. So I knew right away that I didn't want to do any drawing and I also was citing. I didn't want to cite any images. So I thought I'm going to have to do something where maybe I can cut and paste. That would be OK under copyright. I know I wanted to have 
something look... moody, I guess is the word I'm looking for. So I went to [a craft store] and I just looked at all these different papers, and they had these really cool ones with old writing and different textures and stuff.

But anxiety over artistic ability and copyright lead to aesthetic, and poetic, insight:

And then when I saw the different textures, $I$ started thinking about how... that kind of idea of non-unity or disharmony and how Shelley, how "Alastor" is kind of a nonlinear pattern in poetry. So then I was thinking maybe I could put different textures and that to represent it. So I just took a bunch of papers, and I combined it with papers that I had at home, and I took my poster and I just started laying things out and it just kind of came together that way.

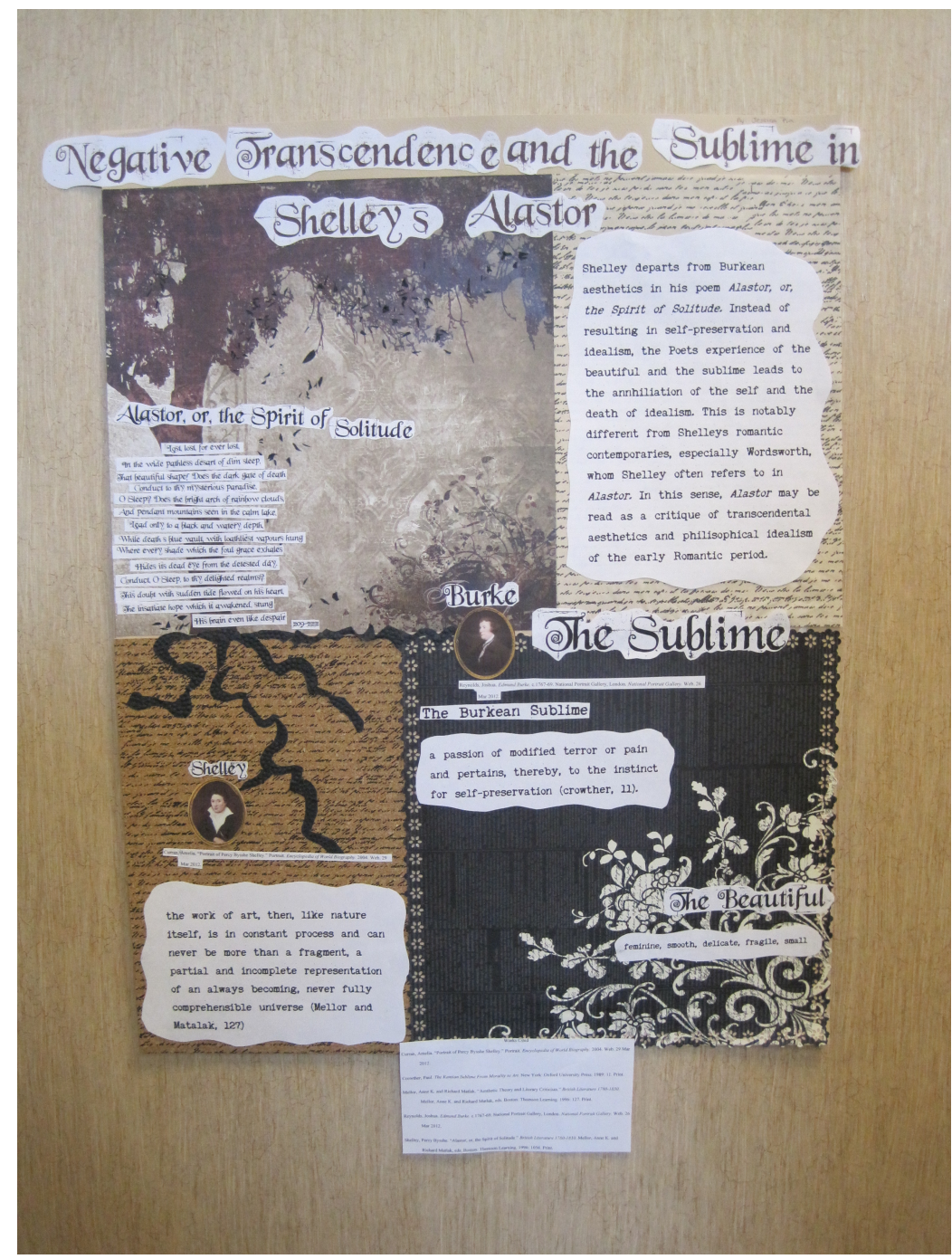

The student starts thinking beyond the plot line of "Alastor" as she tries to represent what she describes as a "non-linear pattern in poetry." She focuses more on ambiguous words and images, joining a scholarly debate about this poem that has been going on since it was written in 1816 . She knows that she wants to use the eighteenth-century aesthetic category of the sublime in her analysis; she has read both Kant's and Burke's descriptions of the sublime. The poster helps her sort through their competing claims:

The one, the paper that had the tree on, then I started thinking maybe I could do a family tree because there's Burke's idea and Kant's idea. So I thought about that, and I even printed Burke and Kant, along with Shelley, because I had those little portraits, but then after I had the three of them kind of on the paper, I realized I don't even really talk about Kant, so I should get rid of that. So having that visual there, I'm like what am I going to put there, it doesn't have anything to do with that, so I just kind of wiped that away. And with Alastor, it's such a beautiful poem; to me it's such a visual poem too. And with tree and everything, I just kind of went off in that direction. 
The cliché of a family tree of ideas turns into something more interesting: the lines from the poem are superimposed on the tree while the roots lead to Shelley and a quotation about Romantic aesthetics by two prominent Romanticists, Anne Mellor and Richard Matlak: "the work of art then, like nature itself, is in constant process and can never be more than a fragment, a partial and incomplete representation of an always becoming, never fully comprehensible universe." As the student works through the intellectual and aesthetic demands of her project, she places her claim in conversation with the primary text, secondary criticism, and a theoretical frame. Her argument about an aesthetic category, the sublime, involves an aesthetic process of experimentation and re-visioning in different media.

\section{Choices that embody claim}

Some students sought to represent their claim through particular effects, often demonstrating remarkable creativity. For example, a poster examining real-life ghost investigations through the lens of the eighteenth-century Gothic tropes played with the uncertainty of the phenomenon, as depending on where the viewer stood, he or she might see someone lurking in the shadows.

The student achieved this effect with a small battery-operated light behind the translucent poster. In a reflection on the poster, she said:

I wanted it to represent the concept I was looking at; because of this, I made it look like a scene from my main text. Shadows were often seen on the property they were investigating so I made a background that showed this. I used dark colors and paint for the trees and grass because they investigate during the night and I wanted to make it look like a nighttime scene; also it allowed for different textures that made it more realistic. I also used

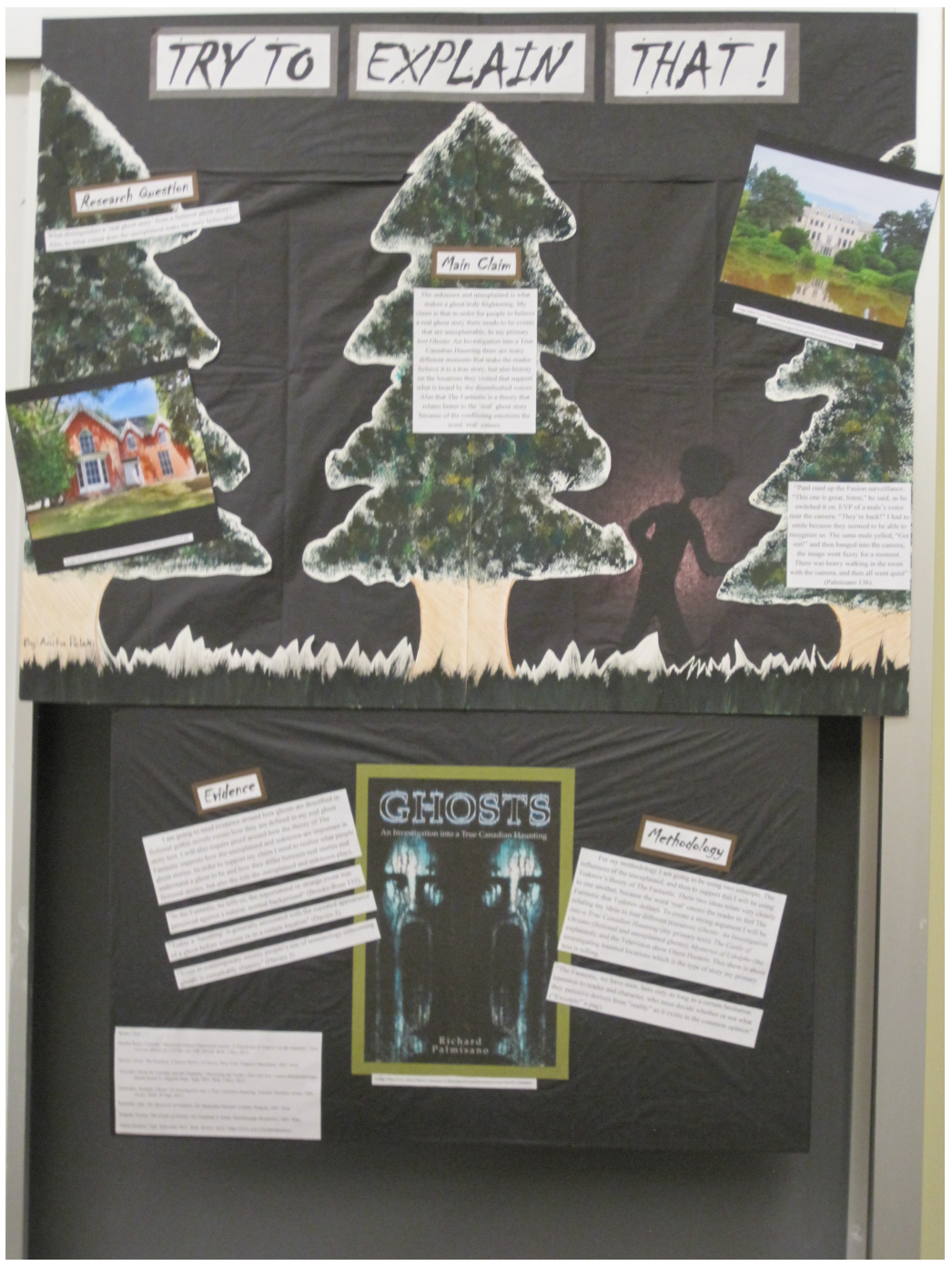
tissue paper to allow for transparency and then placed a foam person behind it to make it look like the shadow figures described in my main text.

However, it was not until conversations with other students during the poster session that she identified a theoretical frame that could help her describe this effect. Another student said that the poster 
reminded him of Todorov's concept of the fantastic. The fantastic is the moment of hesitation between the real and the marvelous, when the individual doesn't know if there is a supernatural explanation. The poster session helped the student find a vocabulary for her essay about the role uncertainty plays in real life ghost stories.

Another student did away with words altogether, at least at first glance. Her poster was a black rectangle with two small triangular oil paintings in the upper right and bottom left corners. The required components of the poster-main claim, theoretical frame, examples of evidence-were there but hidden under flaps. The viewer had to unveil each, mirroring the argument about the indigenous gothic that the student was making. She draws attention to the gothic tradition of the mysterious veil even as she argues for a post-colonial reinterpretation of the genre:

And when we did Udolpho we talked about the idea of a veil, and that triggered for me, even the idea ... like the same kind of themes that people... that you can use when you talk about, I don't know what they call it now, post-colonial literature theory - and the idea of embodying two worlds, and specifically with Gothic the idea of death and how that could be analyzed through perspective, like through different cultural

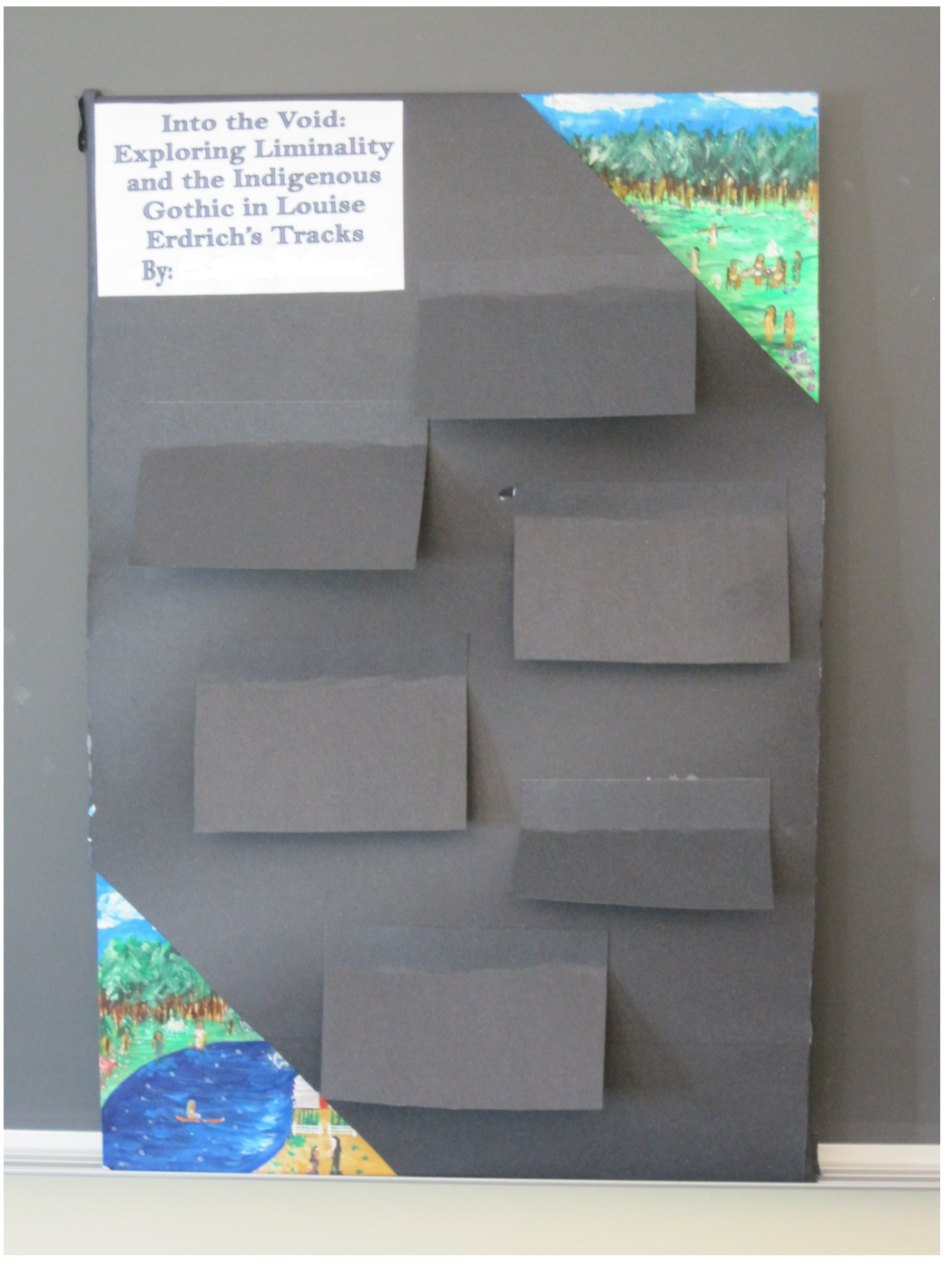
perspectives.

In The Mysteries of Udolpho, a Gothic novel written in 1794 by Ann Radcliffe, the main character peers into a veiled recess and sees something so horrible she swoons; she is later unable to put her experience into words, and so the reader waits for hundreds of pages to discover what she saw. The narrator eventually reveals that she misinterpreted what was behind the veil because she was unable to control her emotions long enough to look closely. Her perspective doesn't allow her to accurately interpret the evidence of her own eyes. The veil is a trope of misreading; indeed, the character never realizes that her interpretation was faulty, that (spoiler alert) instead of a murdered corpse, she saw a wax memento mori designed to focus attention on life through death. The student, examining a $20^{\text {th }}$ century novel by 
Anishinaabe writer Louise Erdich, wanted to challenge Euro-centric assumptions about the afterlife. She deliberately skews the orientation of life and death through the two detailed oil paintings in the corners of the poster. The upper painting represents death, the lower, life, even as each depicts a juxtaposition of Anishinaabe and Roman Catholic cultures. Her poster challenges viewers' expectations about cosmology, culture, and genres, as she claims her primary text does. Instead of drawing viewers to her poster through flashy visuals or large font, she offered blackness, a void that pulls viewers in through her refusal to operate according to poster conventions. She insists that they peer behind the veil, even as she implies that they may misinterpret based on their perspective. In an interview, this student described her initial disappointment in the sample posters I had shown in class; she thought they were boring. She wanted to create "a living visual representation," to turn an essay into art, and art into an essay. Her poster is a deliberate challenge to our assumptions about what the products of literary research should look like.

In some ways, all the posters challenged our assumptions of what the products of literary research should look like. We expect that posters are a science or social science genre, and that English students write research papers, as indeed my students did. However, the posters defamiliarized literary research by making it less about the research paper and more about the process of knowledge creation. They made visible different moments in the process of literary research, moments often elided in the final product. The posters allowed students to create their interpretations through color palette, texture, and layout as well as textual or illustrative elements. These aesthetic choices reflect not only the content but also the tone of the primary texts. Students also had to attract and hold an audience with their posters, sometimes using and discovering strategies that they carried into their final papers. Students had the opportunity to visualize structure, distill the main points, and rehearse the main claim of their arguments, but they also learned from each other. Each student saw a range of approaches and interpretations possible in literary research. They saw behind the veil of the research paper to the processes involved. And perhaps most importantly, posters gave students the opportunity and the confidence to create something of interest to peers as scholars. They began to form an interpretive community, and although they weren't comfortable with challenging each other's ideas in critical debate yet, they were beginning to experience literary research as conversation.

Both creating and presenting the posters changed the way the students thought about the research process and affected the final papers. I cannot claim that posters fixed all the problems we are so used to encountering in the research papers. Students still struggled with tone, with citation, with proportions, with all the elements of writing up a research project, but they at least they had something to write up, something to say. And after all, that is the point of the whole activity. Research involves the creation of knowledge that is then communicated to others; literary research involves the creation of an interpretation, a reading of a particular text. The paper is one oblique measure of the reading, but its requirements and conventions may elide the processes through which the interpretation is reached; the typical audience of one limits its power. The poster can be another, often more accessible, measure of the reading.

\section{MAKING DISCIPLINARY KNOWLEDGE VISIBLE}

I began this paper with the idea of making visible the processes of literary research. Bernstein (2008) argues that there are four audiences for whom learning can and should be made visible: us as instructors, our students, our discipline, and our institution. The posters allowed me to see aspects of the research usually hidden in the conventions of the research paper. Reading the posters reveals key elements of students' interactions with literary texts: close reading, integration, negotiation, theoretical 
generalization, and aesthetic judgment. I was able to provide feedback intended to move these specific projects forward rather than simply commenting on what was done in a paper and offering hypothetical comments of what could be done if the paper were written again. The posters allowed students to recognize different aspects of the research process culminating in dissemination. In order to create these more public interpretations, students had to make deliberate choices, claim authority for those choices, and communicate those choices to their peers. The posters also allowed students to see and learn from their peers' choices.

Reaching Bernstein's third and fourth audiences, the discipline and the higher education community beyond the discipline, requires dissemination beyond the specific classroom, but these audiences may expect very different arguments. The English discipline may be suspicious of the social science conventions of much teaching and learning scholarship; the higher education community may be suspicious of the narrative style of the English scholar. What is convincing to one may be dismissed out of hand by the other. And so I am caught between trying to influence and trying to explain the discipline. I hope colleagues in English studies may be intrigued enough to try posters in their classes even as I hope to make undergraduate literary research visible in the higher education community. This visibility becomes even more important as English departments are under pressure to demonstrate utility and value for money by governments and taxpayers who struggle to understand what we do. We need to show them the creativity and intellectual energy of literary research.

But literary research also has something to offer other disciplines in its attention to how representation affects meaning. These literary research posters included affective, creative, and reflective elements because students were encouraged to depart from the templates. While I recognize that students in science and social science classes need to learn the recognized conventions of the poster genre, what other learning would be possible if they could break these conventions sometimes? Or, even more radically, what other learning would be possible if their inquiry processes were defamiliarized? Kathy Takayama, for example, describes a creative supplement to the laboratory notebook for microbiology students; Reichard and Takayama (2013) note that "engagement with the unfamiliar became a way for students to understand what it means to think in disciplinary ways, especially by moving beyond the expected disciplinary conventions in their learning processes" (p. 169). How can the SoTL community represent and extend that learning? What methodologies, what interpretations, would be acceptable? I return to Stanley Fish's idea of an interpretive community: members do not have to agree, but they do have to consider an interpretation or approach seriously enough to enter into critical, and productive, conversation. Arts and humanities approaches to SoTL have much to offer the larger SoTL community as we all seek to make learning, of many different types, visible.

Karen Manarin is Professor of English and General Education at Mount Royal University; recent publications include the coauthored book Critical Reading in Higher Education: Academic Goals and Social Engagement.

\section{NOTES}

1. My disciplinary colleagues will notice immediately that this paper is not in the Modern Languages Association or even Chicago format, but rather the American Psychological Association format, the preferred style of Teaching \& Learning Inquiry. Different formats encourage different ways of thinking because they emphasize different elements.

2. All students, whether participating in this study or not, completed these assignments as part of the regular course work. In accordance with our university's ethical review process, I did not know until after the courses were completed and the grades assigned who had agreed to have the written work and posters included in this study and who had volunteered to be interviewed. Overall, fifty-nine students 
allowed me to look at their course work for this study. I also conducted eighteen semi-structured interviews to probe what, if any, effect posters had on student learning in a discipline that does not typically use posters for dissemination.

\section{REFERENCES}

Bass, R. (2009). The visible knowledge project. Retrieved Feb 8, 2014 from https://cndls.georgetown.edu/about/grants/vkp/

Bass, R., \& Linkon, S. (2008). "On the evidence of theory: Close reading as a disciplinary model for writing about teaching and learning." Arts and Humanities in Higher Education 7, 245-61.

Behling, L.L. (Ed.). (2009). Reading, writing, and research: Undergraduate students as scholars in literary studies. Washington, DC: Council on Undergraduate Research.

Bernstein, J.L. (2008). Introduction: Making learning visible to whom? The Scholarship of Teaching and Learning at EMU 2(1), Article 2.

Brammer, C., \& Rees, M. (2007). Peer review from the students' perspective: Invaluable or invalid? Composition Studies, 35(2), 71-85.

Chick, N. (2013a). Beyond the essay: Making student thinking visible in the Humanities. Retrieved Feb 8, 2014 from http://cft.vanderbilt.edu/teaching-guides/assessment/beyond-the-essay/

Chick, N. (2013b). The competing metaphors of SOTL: The big tent and the family table. In K. McKinney (Ed.), The scholarship of teaching and learning in and across the disciplines (pp. 15-33). Bloomington, IN: Indiana University Press.

Chick, N. (2011). A humanities SoTL poster: Representing humanist meaning-making. Poster presented at ISSOTL , Milwaukee, WI.

Council for Undergraduate Research. (2011). Retrieved July 8, 2014 from http://www.cur.org/

Donald, J. G. (2009). The Commons: Disciplinary and interdisciplinary encounters. In C. Kreber (Ed.), The university and its disciplines: Teaching within and beyond its disciplinary boundaries (pp. 35-48). New York, NY: Routledge.

Fish, S. (1980). Is There a Text in This Class: The Authority of Interpretive Communities. Cambridge, MA: Harvard University Press.

Grauerholz, L., \& Main, E. (2013). Fallacies of SOTL: Rethinking how we conduct our research. In K. McKinney (Ed.), The scholarship of teaching and learning in and across the disciplines (pp. 152-168). Bloomington, IN: Indiana University Press.

Head, A. J., \& Eisenberg, M. B. (2010). Assigning inquiry: How handouts for research assignments guide today's college students. Project Information Literacy Progress Report. Retrieved Feb 8, 2014 from: http://projectinfolit.org/pdfs/PIL_Handout_Study_finalvJuly_2010.pdf

Kyd, J. (2010). What is the difference between research and scholarship? Retrieved from https://www.youtube.com/watch?v=JlrUWOfEy7w

Linkon, S.L. (2011). Literary learning: Teaching the English major. Bloomington, IN: Indiana University Press.

Manarin, K. (2015, February 11). Exploring common ground? [Web log post]. Retrieved from https://sotlcanada.wordpress.com/2015/02/11/exploring-common-ground/

Mulder, R., Pearce, J., \& Baik, C. (2014). Peer review in higher education: Student perceptions before and after participation. Active Learning in Higher Education, 15(2), 157-171.

Reichard, D.A., \& Takayama, K. (2013). Exploring student learning in unfamiliar territory: A humanist and a scientist compare notes. In K. McKinney (Ed.), The scholarship of teaching and learning in and across the disciplines (pp. 169-185). Bloomington, IN: Indiana University Press.

Schroeder, C., \& Ciccone, A. (Eds.). (2005). Making learning visible. Milwaukee, WI: University of WisconsinMilwaukee. 
Copyright for the content of articles published in Teaching \& Learning Inquiry resides with the authors, and copyright for the publication layout resides with the journal. These copyright holders have agreed that this article should be available on open access under a Creative Commons Attribution License 4.0 International (https://creativecommons.org/licenses/by/4.0). The only constraint on reproduction and distribution, and the only role for copyright in this domain, should be to give authors control over the integrity of their work and the right to be properly acknowledged and cited, and to cite Teaching \& Learning Inquiry as the original place of publication. Readers are free to share these materials-as long as appropriate credit is given, a link to the license is provided, and any changes are indicated. 